\title{
Effects of nicotine on oviducal blood flow and embryo development in the rat*
}

\author{
J. A. Mitchell and R. E. Hammer $\dagger$ \\ Department of Anatomy, Wayne State University School of Medicine, Detroit, Michigan 48201, \\ U.S.A.
}

\begin{abstract}
Summary. Nicotine $(5.0 \mathrm{mg} / \mathrm{kg}$ ) was injected (s.c.) twice daily on Day 1 or Days $1-4$ or 1-5 of pregnancy. Cumulative doses of nicotine retarded embryo cell cleavage and substantially reduced embryo cell number (saline $v$ s nicotine: $42.5 \pm 1.7$ vs $22 \cdot 1 \pm 1.9$ nuclei/embryo, at $12: 00 \mathrm{~h}$ on Day 5; $P<0.05$ ). However, treatment for even 1 day (Day 1) significantly reduced cell number (saline vs nicotine: $42.5 \pm 1 \cdot 7$ vs $30.5 \pm 0.9$, at $12: 00 \mathrm{~h}$ day on Day $5 ; P<0.01)$. Nicotine injection also resulted in a marked and prolonged reduction in oviduct blood flow (pretreatment vs 90 min after nicotine: 0.61 \pm 0.06 vs $0.37 \pm 0.10 \mathrm{ml} / \mathrm{min} \cdot \mathrm{g}^{-1} ; P<0.005$ ). The results indicate that, in the rat, even a brief exposure to nicotine, the chief alkaloid of tobacco, reduces oviducal blood flow and the rate of embryo cell proliferation. The embryo is therefore susceptible to the effects of nicotine before implantation.
\end{abstract}

\section{Introduction}

In women and rats, the course of pregnancy and fetal development is impaired by exposure to nicotine. In women, cigarette smoking has been implicated in such diverse conditions as increased incidence of spontaneous abortion (Hollinshead, 1979), premature delivery (Ochsner, 1971), and low fetal weight (Meredith, 1975). In rats, nicotine treatment similarly retards fetal development, interferes with parturition and reduces birth weight (Becker \& King, 1966; Becker, King \& Little 1968; Hudson \& Timiras, 1972). These well-studied effects are attributable mostly to nicotine impairment of placental function. The present investigation examines the effects of nicotine on pregnancy well before implantation and establishment of the placenta.

The ability of the embryo to adapt to a sub-optimal environment is limited before implantation, and relatively minor perturbations of the environment within the reproductive tract may have marked consequences for conceptus development. The administration of nicotine, for example, to rats during the first 5 days of pregnancy suppressed embryo growth (Card \& Mitchell, 1979; Hammer \& Mitchell, 1979; Hammer, Mitchell \& Goldman, 1979; Yoshinaga, Rice, Krenn \& Pilot, 1979). Such nicotine-induced alterations in embryo growth may result, in part, from reduced uterine blood flow and decreased intrauterine oxygen tension (Hammer, Goldman \& Mitchell, 1981; Mitchell, Hammer \& Goldman, 1983). Similarly, by altering oviducal perfusion, nicotine may impair tubal function and influence embryo development during the initial phase of pregnancy. The following experiments were undertaken to determine whether nicotine reduces tubal blood flow and/or alters the development of the embryo during its passage through the oviduct.

* Reprint requests to: Professor J. A. Mitchell.

† Present address: Laboratory of Reproductive Physiology, Lippincott Building 25th and Locust Streets, Philadelphia, PA 19104, U.S.A. 


\section{Materials and Methods}

Animals. Virgin female rats of the Sprague-Dawley strain (Camm Research Institute, Wayne, New Jersey), 200-350 g body weight, were maintained under environmental conditions controlled with respect to room temperature $\left(20-25^{\circ} \mathrm{C}\right)$, humidity $(40-60 \%)$ and photoperiod $(14 \mathrm{~h} \mathrm{light}, 06: 00-$ $20: 00 \mathrm{~h}$, per $24 \mathrm{~h}$ ). Animals were caged in pairs with free access to Purina Lab Chow and water. Vaginal smears were taken daily to determine the stage of the oestrous cycle. Pro-oestrous animals were placed overnight with a male, and spermatozoa in the vaginal lavage the following morning were taken to indicate mating (Day 1). Daily vaginal smears were continued until the time of autopsy. Pseudopregnancy was induced by stimulating the cervix with a glass rod on the afternoon of pro-oestrus and the morning of oestrus. Day 1 of pseudopregnancy was defined as the last day of vaginal cornification (oestrus) before the onset of the luteal phase.

Nicotine treatment. Treated pregnant animals received a subcutaneous (s.c.) injection of nicotine $(5.0 \mathrm{mg} / \mathrm{kg}$ body weight) twice daily $(10: 00$ and $15: 00 \mathrm{~h})$ on Days $1,1-4$ or $1-5$. One group of rats received injections $(10: 00$ and $15: 00 \mathrm{~h})$ of nicotine $(0.05,0.5$ or $5.0 \mathrm{mg} / \mathrm{kg})$ on Day 1 only. Pseudopregnant rats (Day 5) received a single injection of nicotine $(5.0$ or $0.5 \mathrm{mg} / \mathrm{kg}$ ) before measurement of oviducal blood flow. Control rats received an equivalent volume of physiological saline $(9 \mathrm{~g} \mathrm{NaCl} / 1)$ at comparable times. All nicotine solutions were prepared daily by diluting a concentrated solution ( $98 \%$ nicotine : Eastman Kodak Company) with saline and were refrigerated in brown glass bottles.

Retrieval of embryos. At 12:00 h on Days 2, 3, 4 or 5 of pregnancy, animals were anaesthetized with ether and ovaries and oviducts were removed. Under a dissecting microscope, the ovarian bursa was opened, a blunted 30-gauge hypodermic needle was inserted into the ostium and the oviduct was flushed with $0.1 \mathrm{ml}$ saline. The flushings were collected in a depression slide and conceptuses were counted at $\times 40$ magnification.

Determination of cell number. The cells of each embryo were dispersed and their nuclei were stained and counted (Tarkowski, 1966). Preparations were discarded if overlapping of cells impaired accurate counting.

Determination of oviducal blood flow. On the afternoon of Day 5 of pseudopregnancy, animals were anaesthetized with an intraperitoneal injection of pentobarbitone sodium $(40 \mathrm{mg} / \mathrm{kg})$ about 15 min before blood flow measurement. Rats were injected subcutaneously with saline or nicotine (5.0 or $0.5 \mathrm{mg} / \mathrm{kg}$ body wt). At $10,20,45,90$ or $120 \mathrm{~min}$ thereafter, blood flow was measured (Hammer $e t$ al., 1981). Oviducts were removed, cleaned of connective tissue and weighed to the nearest $0 \cdot 1 \mathrm{mg}$. Radioactive indicator content was determined in a Packard auto-gamma counter. Nutritive blood flow, defined as the exchangeable portion of total blood flow, was expressed as $\mathrm{ml} / \mathrm{min} \cdot \mathrm{g}^{-1}$ tissue. Since in control rats oviducal blood flow did not change with time, measurements were pooled to provide the control mean (time 0 ).

Statistical analysis. Sample means from control and experimental groups were compared for significance of differences by a two-tailed Student's $t$ test. A $P$ value of $<0.05$ was assumed to indicate a statistically significant difference between groups.

\section{Results}

Cumulative doses of nicotine retarded cell cleavage (Table 1). After 3 nicotine injections $(12: 00 \mathrm{~h}$, Day 2), the cleavage rate of nicotine-treated embryos lagged behind that of controls and the delay in cleavage persisted after 5 nicotine injections $(12: 00 \mathrm{~h}$, Day 3). Retardation of cleavage in embryos of treated animals was even more marked after 7 nicotine injections (12:00 h, Day 4); whereas none of the control embryos remained in the 4-cell stage, $70 \%$ of the embryos of treated rats 
Table 1. Effect of nicotine ( $5 \mathrm{mg} / \mathrm{kg}, 10: 00$ and $15: 00 \mathrm{~h}$, Days 1-4) on oviducal embryo cell cleavage

\begin{tabular}{|c|c|c|c|c|c|c|c|c|c|}
\hline \multirow[b]{3}{*}{ Treatment } & \multicolumn{9}{|c|}{$\%$ Cell cleavage state at $12: 00 \mathrm{~h}$ on: } \\
\hline & \multicolumn{3}{|c|}{ Day 2} & \multicolumn{3}{|c|}{ Day 3} & \multicolumn{3}{|c|}{ Day 4} \\
\hline & 1-cell & 2-cell & 4-cell & 2 -cell & 3-cell & 4-cell & 4-cell & 8-cell & 10-cell \\
\hline Control & $\begin{array}{l}7 / 27 \\
(26)\end{array}$ & $\begin{array}{c}20 / 27 \\
(74)\end{array}$ & $\begin{array}{c}0 / 27 \\
(0)\end{array}$ & $\begin{array}{c}30 / 68 \\
(44)\end{array}$ & $\begin{array}{c}1 / 68 \\
(2)\end{array}$ & $\begin{array}{c}37 / 68 \\
(54)\end{array}$ & $\begin{array}{c}0 / 49 \\
(0)\end{array}$ & $\begin{array}{c}39 / 49 \\
(80)\end{array}$ & $\begin{array}{c}10 / 49 \\
(20)\end{array}$ \\
\hline Nicotine & $\begin{array}{c}12 / 32 \\
(38)\end{array}$ & $\begin{array}{c}18 / 32 \\
(56)\end{array}$ & $\begin{array}{c}2 / 32 \\
(6)\end{array}$ & $\begin{array}{c}11 / 18 \\
(61)\end{array}$ & $\begin{array}{c}0 / 18 \\
(0)\end{array}$ & $\begin{array}{l}7 / 18 \\
(39)\end{array}$ & $\begin{array}{c}21 / 30 \\
(70)\end{array}$ & $\begin{array}{l}9 / 30 \\
(30)\end{array}$ & $\begin{array}{c}0 / 30 \\
(0)\end{array}$ \\
\hline
\end{tabular}

Values are no. of embryos in designated stage of cleavage over total number of embryos retrieved with $\%$ of embryos in parentheses.

Table 2. Effect of nicotine ( $5 \mathrm{mg} / \mathrm{kg}, 10: 00$ and $15: 00 \mathrm{~h}$, Days 1-4) on mean number of nuclei/embryo

\begin{tabular}{|c|c|c|c|c|}
\hline \multirow[b]{3}{*}{ Treatment } & \multicolumn{4}{|c|}{ Number of nuclei/embryo } \\
\hline & \multirow{2}{*}{$\frac{\text { Day } 2}{12: 00 \mathrm{~h}}$} & \multirow{2}{*}{$\frac{\text { Day } 3}{12: 00 \mathrm{~h}}$} & \multicolumn{2}{|c|}{ Day 4} \\
\hline & & & $12: 00 \mathrm{~h}$ & $18: 00 \mathrm{~h}$ \\
\hline $\begin{array}{l}\text { Control } \\
\text { Nicotine }\end{array}$ & $\begin{array}{l}1.7 \pm 0.1(27) \\
1.6 \pm 0.1(20)\end{array}$ & $\begin{array}{l}3.1 \pm 0.1(68) \\
2.5 \pm 0.2(18)\end{array}$ & $\begin{array}{l}8.4 \pm 0.8(51) \\
4.9 \pm 0.4^{*}(30)\end{array}$ & $\begin{array}{r}12.6 \pm 0.1 \quad(20) \\
8.6 \pm 0.1^{*}(27)\end{array}$ \\
\hline
\end{tabular}

Values are means \pm s.e.m. for number of embryos indicated in parentheses.

* Values significantly different from respective control value: $P<0.001$.

remained at the 4-cell stage, and although $20 \%$ of control embryos had attained the 10-cell stage, none of the nicotine-treated embryos were advanced beyond the 8-cell stage of cleavage.

The effects of nicotine treatment during the first 4 days of pregnancy on mean embryo cell number are shown in Table 2. Although the embryos of nicotine-treated rats consistently possessed fewer cells than those retrieved from saline-injected animals the difference was not statistically different until Day 4. Cell number remained reduced (32\%) in embryos after they had entered the uterus (18:00 h, Day 4).

Nicotine treatment for 4 days reduced embryo cell number by about $50 \%$ in blastocysts retrieved at $12: 00 \mathrm{~h}$ on Day 5 (Table 3). Even one day of treatment (i.e. 2 injections) substantially reduced cell number. Nicotine treatment did not alter the number of blastocysts recovered.

Table 3. Effects of various nicotine regimens on mean number of nuclei/embryo

\begin{tabular}{|c|c|c|c|c|}
\hline \multirow[b]{2}{*}{ Group } & \multicolumn{2}{|c|}{ Treatment } & \multicolumn{2}{|c|}{$12: 00 \mathrm{~h}$, Day 5} \\
\hline & $\begin{array}{c}\text { Time } \\
\text { (days) }\end{array}$ & $\begin{array}{c}\text { Dose } \\
(\mathrm{mg} / \mathrm{kg})\end{array}$ & $\begin{array}{l}\text { Mean no. of blastocysts } \\
\text { retrieved/horn }\end{array}$ & $\begin{array}{c}\text { Mean no. of } \\
\text { nuclei/blastocyst }\end{array}$ \\
\hline Cont & $1-5$ & 0 & $5.5 \pm 0.5$ & $42.5 \pm 1.7(50)$ \\
\hline Nicotine & $\begin{array}{l}1-5 \\
1 \\
1 \\
1\end{array}$ & $\begin{array}{l}5 \cdot 0 \\
0 \cdot 05 \\
0 \cdot 50 \\
5 \cdot 0\end{array}$ & $\begin{array}{l}5.2 \pm 0.7 \\
5.3 \pm 0.6 \\
5.4 \pm 0.4 \\
5.2 \pm 0.5\end{array}$ & $\begin{array}{l}22 \cdot 1 \pm 1 \cdot 9^{*}(20) \\
41.5 \pm 2 \cdot 4(10) \\
42.7 \pm 1 \cdot 3(30) \\
30.5 \pm 0.9^{* *}(40)\end{array}$ \\
\hline
\end{tabular}

Values are means \pm s.e.m.; no. of embryos indicated in parentheses.

Values significantly different from respective control values: ${ }^{*} P<0.05$, **P $<0.01$. 
Table 4. Effects of a single injection of nicotine on mean \pm s.e.m. oviducal blood flow and cardiac output of rats

\begin{tabular}{|c|c|c|c|c|c|c|}
\hline & \multicolumn{6}{|c|}{ Time after injection (min) } \\
\hline & 0 & 10 & 20 & 45 & 90 & 120 \\
\hline & Control & \multicolumn{5}{|c|}{$5.0 \mathrm{mg}$ nicotine $/ \mathrm{kg}$} \\
\hline $\begin{array}{l}\text { No. of rats } \\
\text { Oviducal blood } \\
\text { flow } \\
\left(\mathrm{ml} / \mathrm{min} \cdot \mathrm{g}^{-1}\right)\end{array}$ & $\begin{array}{c}5 \\
0.61 \pm 0.06\end{array}$ & $\begin{array}{c}6 \\
0.45 \pm 0.08^{* *}\end{array}$ & $\begin{array}{c}7 \\
0.40 \pm 0.08^{* * *}\end{array}$ & $\begin{array}{c}5 \\
0.38 \pm 0.06^{* * *}\end{array}$ & $0.37 \pm 0 \cdot 10^{* * *}$ & $\begin{array}{c}8 \\
0.55 \pm 0.08\end{array}$ \\
\hline $\begin{array}{l}\text { Cardiac output } \\
\left(\mathrm{ml} / \mathrm{min} \cdot \mathrm{kg}^{-1}\right)\end{array}$ & $414 \pm 14$ & $388 \pm 29$ & $403 \pm 46$ & $313 \pm 29^{*}$ & $317 \pm 21^{*}$ & $364 \pm 24$ \\
\hline & Control & \multicolumn{5}{|c|}{$0.5 \mathrm{mg}$ nicotine $/ \mathrm{kg}$} \\
\hline $\begin{array}{l}\text { No. of rats } \\
\text { Oviducal blood } \\
\text { flow } \\
\left(\mathrm{ml} / \mathrm{min} \cdot \mathrm{g}^{-1}\right)\end{array}$ & $\begin{array}{c}5 \\
0.61 \pm 0.06\end{array}$ & $\begin{array}{c}5 \\
0.61 \pm 0.06\end{array}$ & $\begin{array}{c}6 \\
0.55 \pm 0.07\end{array}$ & $\begin{array}{c}5 \\
0.57 \pm 0.05\end{array}$ & $0.39 \pm \frac{5}{0.09^{* *}}$ & $\begin{array}{c}5 \\
0.45 \pm 0.08\end{array}$ \\
\hline $\begin{array}{l}\text { Cardiac Output } \\
\left(\mathrm{ml} / \mathrm{min} \cdot \mathrm{kg}^{-1}\right)\end{array}$ & $414 \pm 14$ & $468 \pm 11$ & $431 \pm 42$ & $446 \pm 33$ & $469 \pm 14$ & $404 \pm 45$ \\
\hline
\end{tabular}

Values significantly different from that at $0 \mathrm{~min}:{ }^{*} P<0.01,{ }^{* *} P<0.025,{ }^{* * *} P<0.005$.

The effects of nicotine on oviducal blood flow are shown in Table 4. The pattern of changes in blood flow after nicotine administration was dose-dependent. Injection of $5.0 \mathrm{mg} / \mathrm{kg}$ resulted in a marked and prolonged reduction in oviducal blood flow. Oviducal perfusion was reduced at $10 \mathrm{~min}$ after injection and remained suppressed for $90 \mathrm{~min}$ before returning to control levels by $120 \mathrm{~min}$. Cardiac output was depressed at 45 and $90 \mathrm{~min}$. The lower dose of nicotine $(0.5 \mathrm{mg} / \mathrm{kg}$ body wt) did not significantly depress tubal blood flow until $90 \mathrm{~min}$ after injection and perfusion rapidly returned to control levels.

\section{Discussion}

Although the doses of nicotine used in the present experiments exceed those encountered during cigarette smoking (Armitage et al., 1975; Russell, Wilson, Patel, Feyerabend \& Cole, 1975), the results clearly indicate that, in the rat, even a brief exposure to nicotine reduces tubal blood flow and embryo cell proliferation. Accordingly, during the preimplantation period, the embryo is susceptible to nicotine effects and the consequences of delayed development persist beyond the period of nicotine exposure.

Nicotine may act directly on the embryo. The alkaloid is readily taken up by the uterine fluid and accumulated by blastocysts (Fabro \& Sieber, 1969; McLachlan, Dames, Sieber \& Fabro, 1976). Furthermore, nicotine acts directly on cells to alter cytokinesis: low doses of nicotine $\left(6 \cdot 17 \times 10^{-6}\right.$ M) stimulate division of HeLa cells; high concentrations $\left(3.09 \times 10^{-3} \mathrm{M}\right)$ prolong metaphase (Ved Brat, Sisken \& Anderson, 1979). Whether embryoblasts differ in susceptibility to the growthretarding effects of nicotine is under investigation. Alterations in trophoblast-dependent events (time of zona loss, implantation) coupled with the absence of embryopathy suggest that nicotineinduced suppression of cell division may be occurring primarily in the trophoblast.

In addition to delaying the occurrence of first cleavage and reducing the rate of embryonic cell proliferation, daily injection (Days $1-4$ ) of $5 \mathrm{mg}$ nicotine/ $\mathrm{kg}$ delays the time of zona pellucida loss and modestly retards implantation (Card \& Mitchell, 1979; Hammer \& Mitchell, 1979). Nevertheless, litter size is not altered in rats receiving nicotine and their young do not differ from those of controls with respect to birth weight, sex distribution or mortality (Hammer \& Mitchell, 1979). Furthermore, preliminary observations indicate no increase in the rate of fetal 
malformations in litters of nicotine-treated rats (R. E. Hammer \& J. A. Mitchell, unpublished data). Nicotine treatment during the initial 4 days of pregnancy does not impair post-partum body growth; it does, however, delay the onset of puberty (Mitchell \& Hammer, 1984).

Nicotine may modify embryo development indirectly by altering the intramural environment of the oviduct. By modifying oestrogen and/or progesterone secretion (Yoshinaga et al., 1979; R. E. Hammer \& J. A. Mitchell, unpublished observations), nicotine may retard early embryonic development by altering tubal fluid composition. However, since only two injections of nicotine are required to delay conceptus growth, whereas multiple doses at frequent intervals are generally required to alter hormone secretion markedly (Blake, Scaramuzzi, Norman, Kanematsu \& Sawyer, 1972), it appears unlikely that hormone imbalance plays a major role in modifying embryo cell proliferation. Rather, nicotine-induced suppression of tubal blood flow is more likely to account for the observed decrease in cell proliferation. Blood flow is of major importance in the production of tubal fluid; both its volume and composition are influenced by tubal haemodynamics (Hamner, 1973). Therefore, agents such as nicotine, which alter blood flow, may potentially modify the luminal environment and thereby adversely affect pregnancy.

Oxygen is among the essential metabolic substrates provided by the oviduct to the developing conceptus. Normal embryo development requires an optimal level of oxygen (Sugawara \& Umezu, 1961), and the concentration of oxygen demanded by the embryo increases as development proceeds (Brinster, 1972). As with intrauterine oxygen tension (Mitchell \& Yochim, 1968a, b), the primary determinant of oxygen availability within the oviduct appears to be tubal haemodynamics (Mastroianni \& Jones, 1965). Nicotine-induced suppression of uterine blood flow is achieved, in part, by systemic discharge of catecholamines (Resnik, Brink \& Wilkes, 1979). The oviduct, like the uterus, receives adrenergic innervation (Norberg \& Fredericsson, 1966) with many nerves terminating on tubal vessels (Brundin, 1965, 1969). The fact that the time-course of the haemodynamic response of the oviduct to the alkaloid was virtually identical to that of the uterus (Hammer et al., 1981; Mitchell et al., 1983) suggests that nicotine-induced vasoconstriction of the oviducal vasculature is also mediated by systemic and/or local catecholamine release.

If nicotine alters oviducal perfusion via catecholamine release, then cigarette smoking may exert significant adverse effects on early pregnancy in women. It is known that the quantity of nicotine absorbed from cigarette smoke, though markedly less than the levels achieved in the present experiment, is, nevertheless, sufficient to elevate plasma catecholamine levels (Quigley, Sheehan, Wilkes \& Yew, 1979), reduce uterine perfusion (Resnik, Brink \& Wilkes, 1979) and produce transient fetal hypoxia (Manning \& Feyerabend, 1976). Since the human oviduct and its vessels, like the uterus, are innervated by adrenergic nerves (Brundin \& Wirsen, 1964), it is possible that cigarette smoking could reduce oviducal blood flow and produce a suboptimal oviducal environment for embryo growth by decreasing the availability of oxygen and other metabolic substrates. While intraoviducal oxygen tension has not been measured in women, observations of monkeys suggest that there is a finely tuned balance within the oviduct between the oxygen supply and $\mathrm{O}_{2}$ demand by the embryo (Maas, Storey \& Mastroianni, 1976). If oxygen reserves are similarly limited in the human oviduct, the embryo may be at risk in the presence of even brief periods of oviducal hypoxia. As with the uterus, the quantity of nicotine absorbed from tobacco smoke may be sufficient to reduce oviducal blood flow and cause episodes of oxygen insufficiency. The development of the embryo may therefore be modified while still within the oviduct.

A pilot project relating to this study was supported in part by a Grant-in-Aid of Research to R.E.H. by the Society of Sigma Xi, 1981. This work was supported by a grant to J.A.M. from the Council for Tobacco Research, Inc., USA (No 1351). This research is part of a dissertation by R.E.H. submitted to the Graduate School of Wayne State University in partial fulfilment of the requirements for the degree of Doctor of Philosophy. We thank Sharon Murphy for help in measuring blood flow and Dr Bent G. Boving for helpful suggestions and careful review of the manuscript. 


\section{References}

Armitage, A.K., Dollery, C.T., George, C.F., Houseman, T.H., Lewis, P.J. \& Turner, D.M. (1975) Absorption and metabolism of nicotine from cigarettes. Br. med. J. 4, 313-316.

Becker, R.F. \& King, J. (1966) Studies on nicotine absorption during pregnancy. II. The effects of acute heavy doses on mother and neonates. Am. J. Obstet. Gynec. 95, 515-522.

Becker, R.F., King, J.E. \& Little, C. (1968) Experimental studies on nicotine absorption during pregnancy. IV. The postmature neonate. Am. J. Obstet. Gynec. 101, $1109-1119$.

Blake, C.A., Scaramuzzi, R., Norman, R., Kanematsu, S. \& Sawyer, C. (1972) Effect of nicotine on the proestrous ovulatory surge of $\mathrm{LH}$ in the rat. Endocrinology 91, 1253-1258.

Brinster, R.L. (1972) Developing zygote. In Reproductive Biology, pp. 748-775. Eds H. Balin \& S. Glasser. Excerpta Medica, Amsterdam.

Brundin, J. (1965) Distribution and function of adrenergic nerves in the rabbit fallopian tube. Acta physiol. scand., Suppl. 59, 1-57.

Brundin, J. (1969) Pharmacology of the oviduct. In The Mammalian Oviduct, pp. 251-269. Eds E. Hafez \& R. J. Blandau. University of Chicago Press, Chicago.

Brundin, J. \& Wirsen, C. (1964) Adrenergic nerve terminals in the human Fallopian tube examined by fluorescence microscopy. Acta physiol. scand 61, 505506.

Card, J.P. \& Mitchell, J.A. (1979) The effects of nicotine on implantation in the rat. Biol. Reprod. 20, 532-539.

Fabro, S. \& Sieber, S. (1969) Caffeine and nicotine penetrate the preimplantation blastocyst. Nature, Lond. 223, 410-411.

Hammer, R.E. \& Mitchell, J.A. (1979) Nicotine reduces embryo growth, delays implantation, and retards parturition in rats. Proc. Soc. exp. Biol. Med. 162, 333-336.

Hammer, R.E., Mitchell, J.A. \& Goldman, H. (1979) Effects of nicotine on conceptus cell proliferation and oviducal/uterine blood flow in the rat. In Cellular and Molecular Aspects of Implantation, pp. 439-442, Eds. S. Glasser \& D. Bullock. Plenum Publishing Corp., New York.

Hammer, R.E., Goldman, H. \& Mitchell, J.A. (1981) Effects of nicotine on uterine blood flow and intrauterine oxygen tension in the rat. J. Reprod. Fert. 63, 163-168.

Hamner, C.E. (1973) Oviductal fluid-composition and physiology. In Handbook of Physiology, Endocrinology, Vol. 2, Part 2, pp. 145-151. Eds R. O. Greep \& E. B. Astwood. Williams and Wilkins, Baltimore.

Hollinshead, N.H. (1979) The consequences of smoking in pregnancy. Rhode Island. Med. J. 62, 207-212.

Hudson, D.B. \& Timiras, P.S. (1972) Nicotine injection during gestation: impairment of reproduction, fetal viability and development. Biol. Reprod. 7, 247-253.

Maas, D.H., Storey, B.T. \& Mastroianni, L. (1976) Oxygen tension in the oviduct of the rhesus monkey (Macaca mulatta). Fert. Steril. 27, 1312-1317.

Manning, F.A. \& Feyerabend, C. (1976) Cigarette smoking and fetal breathing movements. $\mathrm{Br}$. J. Obstet. Gynaec. 83, 262-270.
Mastroianni, L. \& Jones, R. (1965) Oxygen tension within the rabbit fallopian tube. J. Reprod. Fert. 9, 99-102.

McLachlan, J., Dames, H., Sieber, S. \& Fabro, S. (1976) Accumulation of nicotine in the uterine fluid of the six-day pregnant rabbit. Fert. Steril. 27, 1204-1213.

Meredith, H.V. (1975) Relationship between tobacco smoking of pregnant women and body size of their progeny: a compilation and synthesis of published studies. Human Biol. 47, 451-472.

Mitchell, J.A. \& Yochim, J.M. (1968a) Intrauterine oxygen tension during the estrous cycle in the rat: its relation to uterine respiration and vascular activity. Endocrinology 83, 701-705.

Mitchell, J.A. \& Yochim, J.M. (1968b) Measurement of oxygen tension in the rat and its regulation by ovarian steroid hormones. Endocrinology 83, 691-700.

Mitchell, J.A. \& Hammer, R.E. (1984) Effects of nicotine on blastocyst development prior to implantation in the rat. In Physiological and Pharmacological Control of Nervous System Development. Ed. E. Giacobini. Elsevier Science Publishers, Amsterdam. (In press).

Mitchell, J.A., Hammer, R.E. \& Goldman, H. (1983) Concomitant reduction in uterine blood flow and intrauterine oxygen tension in the rat following nicotine administration. In Oxygen Transport to Tissue IV, pp. 231-241. Eds H. Bicher \& D. Bruley. Plenum Publishing Corp., New York.

Norberg, K.A. \& Fredricsson, B. (1966) Cellular distribution of monoamines in the uterine walls and tubal walls of the rat. Acta physiol. scand. 68, Suppl. 277, 149.

Ochsner, A. (1971) The health menace of tobacco. Am. Sci. 59, 246-252.

Quigley, M.E., Sheehan, K.L., Wilkes, M.M. \& Yew, S.S.C. (1979) Effects of maternal smoking on circulating catecholamine levels and fetal heart rates. Am. J. Obstet. Gynec. 133, 685-690.

Resnik, R., Brink, G.W. \& Wilkes, M. (1979) Catecholamine-mediated reduction in uterine blood flow after nicotine infusion in the pregnant ewe. J. clin. Invest. 63, 1133-1136.

Ruscell, M.A.H., Wilson, C., Patel, V.A., Feyerabend, C. \& Cole, P.V. (1975) Plasma nicotine levels after smoking cigarettes with high, medium and low nicotine yields. Br. med. J. 2, 414-416.

Sugawara, S. \& Umezu, M. (1961) Studies on metabolism of the mammalian ova. II. Oxygen consumption of the cleaved ova of the rat. Tohoku J. agric. Res. 12, 17-28.

Tarkowski, A. (1966) An air-drying method for chromosome preparations from mouse eggs. Cytogenetics 5 , 394-400.

Ved Brat, S.S., Sisken, J.E. \& Anderson, R.L. (1979) The effects of nicotine on cell division of Hela cells. Eur. J. Cell Biol. 19, 250-254.

Yoshinaga, K., Rice, C., Krenn, J. \& Pilot, R.L. (1979) Effects of nicotine on early pregnancy in the rat. Biol. Reprod. 20, 294-303. 